\title{
Deranging Oneself in Someone Else's House
}

\author{
Hannah Lewi
}

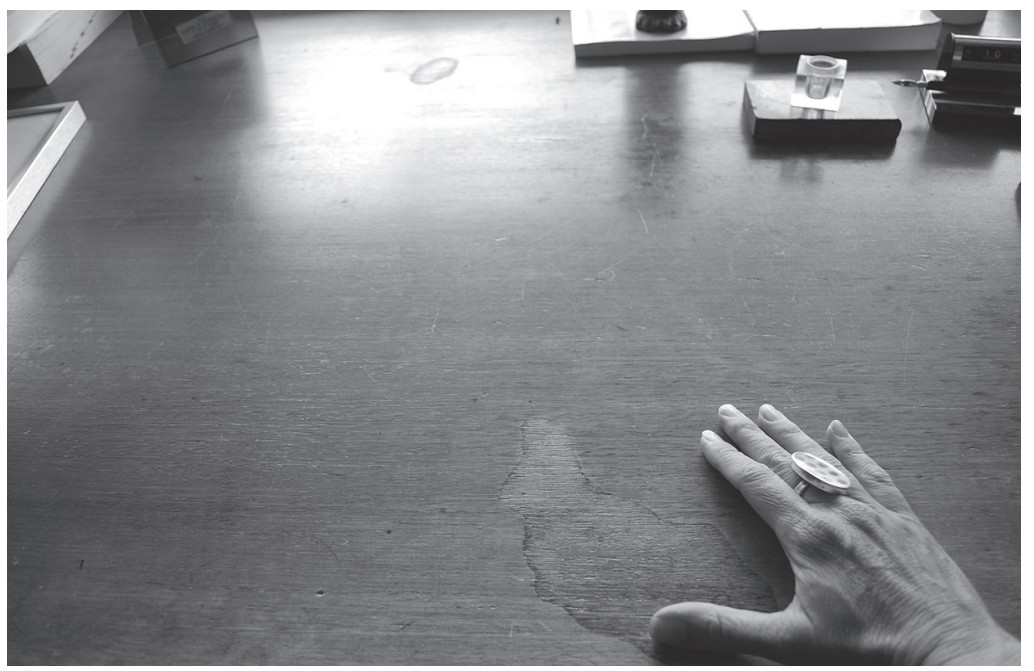

Image credit: All images in this paper by the author, Manning Clark House visit, 2011

Such a house, killed by its very emptiness and the superstitions that have built up in the region, is a haunted house [une maison visionee]. The devil comes there in the night. (Anthony Vidler 1992)

The following piece of writing is part of a larger project that reflects on iconic or significant houses that have, in some mode or another, been transformed into a genre of image-object that architecturalises and disseminates historiography, primarily through the art of mnemotechnics. The research asks how we come to know and experience houses that are not necessarily our own, but that we have more than limited access to because they have been retained as embalmed objects of shared interest? Of particular concern to my study are twentieth-century houses that have been preserved in a suspended or memorialised state of seminewness because of their importance to the historiography of Modernity: a history intimately bound up with elevating the domestic and the private to the realm of architectural significance. The writing teases out claims made about the potency of shared memories residing in museum-houses, and the roles they play as document-objects.

I have set myself the research program of attempting to stay for extended periods in a range of these modern heritage or museum-houses. The rationale is to chart the unfolding experience of sites that are on the one hand still homes, yet also acknowledged as public places. These houses are therefore somehow familiar yet also strangers. J. G. Ballard imagined in his story The Thousand Dreams of Stella Vista (1962) a psychotropic house equipped with sensory memory cells that could adjust the ambient mood of the house to the pleasures or anxieties of those who inhabited it. However, even without such wizardry, houses are potent domestic sites of embodied histories, memories and experiences that also frame our own inner identities, anxieties and memories.

What follows is a story about coming to know such a house as an "image-object": the house where the Australian historian Manning Clark lived in Canberra for his later life. It is written in part as a travel diary documenting personal experience, 

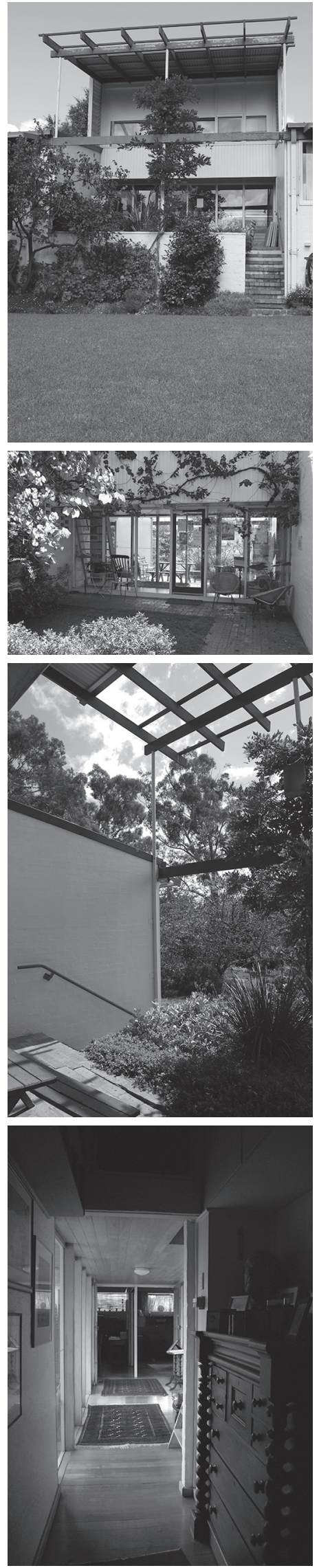

in part as a theoretical explication, and in part as notes towards an unfolding three-episode play. Although perhaps unconventional, this mode of writing seems appropriate for heritage interpretation which, as a mode of history-telling, borrows heavily from the dramatic genre to create displays that are part "real" and part "fabrication". By self-consciously exploiting alternative narrative voices, this piece contributes to the exploration of topologies of memorialising the past that are sensory, gestural and imaginary, and that perhaps uncover some glimpses into the psychic character of such museum-houses for the architectural historian. The writing is intentionally fragmented and episodic, and retains all the awkward bumps of personal experience and revelation. The writing wants to dangerously stray across academic territories: history, biography, and architectural documentation. As John Docker has advised on the writing of history:

... to potentially derange texts from the usual kinds of treatment they receive - one has to take risks - one has to derange oneself, make sideways moves, go over the top and keep going, journey deep within oneself. One has to cultivate method as a kind of madness. (2000)

\section{EPISODE ONE: first impressions}

I held no particular regard for the now somewhat infamous historian Manning Clark before this visit. I was more interested in his house, designed by Robin Boyd in 1952. Navigating my way through the ring-roads of Canberra I arrive outside the discretely engraved Manning Clark House sign in Tasmania Circle in the suburb of Forrest, the original heart of Walter Burley Griffin's plan of the southern residential area of the city. There are other small signs of organisational formality not usually found in a private house: a poster of upcoming Manning Clark Foundation events; a portrait of Clark; a visitor sign-in book on the entry table.

I drop my bag and laptop on the rug inside the door. Through the glazed hall I see a man sitting at a wooden table in the courtyard on the other side of the house. $\mathrm{He}$ is reading with a large pot of tea in front of him. He gets up and shakes my hand enthusiastically, and introduces himself as one of Manning Clark's sons: "Would you like a quick tour of the house?”

What is he doing here?

\section{Does he live here?}

\section{Do I have to share my weekend with him?}

He tells me that this outside courtyard is a long-time favourite place to sit and catch some northern sun. Interspersed between staccato questions about who I am and what I am doing here, he offers to show me around the house before he needs to catch his bus back to Sydney. At a quick glance the house uses a familiar Boyd palette: lightly bagged brick walls, pale painted timber frames, expressed raked ceilings and timber floors. I tell him of my interest in Robin Boyd, so he obliges by talking a little about the architecture.

Why Boyd? Well, so the story goes, his mother Dymphna Clark had already noticed Boyd's work in Home Beautiful magazines. And then Manning came home from a party in 1948 saying he had just met a marvellous architect, and that if they ever built another house he would be the architect they would use... "Yes, dear," 
said Dymphna, with skilled indulgence. Axel Clark described Boyd as a "fastidious, thin-lipped man who despised beer drinking, mateship and the crudity of so much that passed for culture in Australia”.

We start with the Manning Clark Foundation's office which was originally Manning and Dymphna's bedroom, and then peek into two other single bedrooms - one he calls "the boys' room" and points to the ample built-in wardrobe space and built-in shelves that house the hundreds of books in each room.

BOOKS: Shelves in every room full of orderly labelled collections of literature, Australian history and geography, bibles, art books .... some 10,000. Benedict Clark recalls: "Dad was always buying books ... Mum would see a pile of books come through the door and she'd sort of faint, then go around and show him the place on the bookshelf where he already had them all."

These books already begin to give an uncanny feeling of another family home - a creeping hunger that overtakes the children's bedrooms. And this feeling grows and adds to my disquiet over the duration of the weekend.

We tour the bathrooms and I try to sound knowledgeable by pointing out Boyd's characteristic layered combination of glass louvres, fly-screens and breeze blocks. I am then directed down the hall, past many family photos and two busts of Manning and Dymphna sitting on a dresser, and invited to climb with care the vertical ladder up to Father's study. Perched away from and above the rest of the house, it forms an eyrie.

My first impression is of a full room: full of work, full of books, objects, papers, and full of the egotistical presence of someone. On the bookshelves are rows of copies of various imprints of Clark's own books. And much space is devoted to Russian works of literature - Tolstoy, Dostoyevsky - displayed as a literary lineage or destiny, I wonder?

A large wooden desk overlooks the broad window with a view onto the garden. The "computer" is pointed out to me as the ink pen in the drawer of this desk. I am invited to "touch that":

Father wrote just about everything he ever published at this desk - ink stains seeping through into the wood-grain - there is a smooth patch on the desk, where father's hand always rested while writing ... One PhD student who stayed here had to turn the desk away from the window so she could get any writing done.

It is not possible to take in this room at first glance and I make a note to myself that I must return if I want to get to know this house at all. We climb back down the step-ladder. The kitchen still has all original cabinets and old cooker. It is modest and cheerfully domestic with blue spotted curtains, blue and white crockery and glasses on show. It is welcoming and easy, not like the study.

Boyd wanted dark soft red for the living room ceiling. Dymphna settled for galah pink. He wanted as much light as possible. She worried about the 10-square-metre glass window in the living room, and the bagged interior walls, and the brick outside which she thought would need to be painted too often. Boyd reassured her: "bricks look good when the paint is peeling off". The house was surprisingly
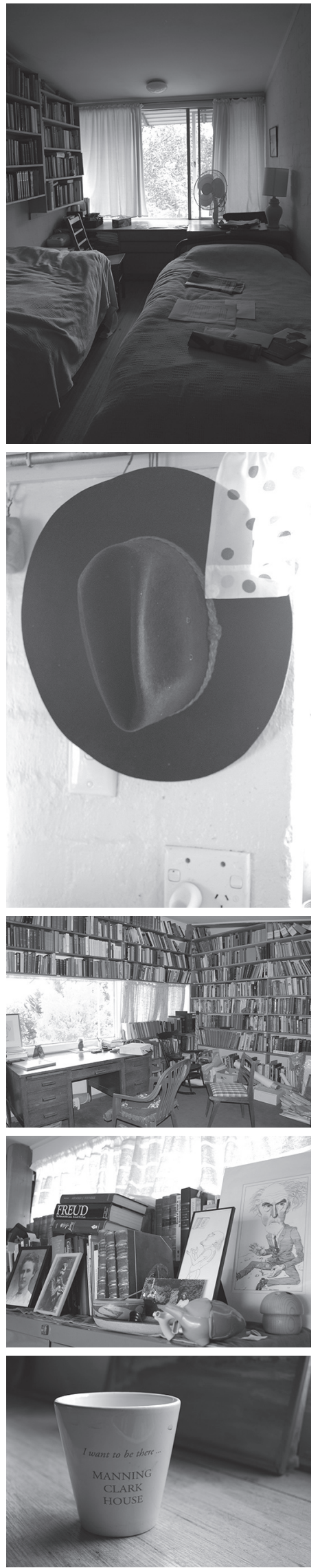
expensive for the early 1950s, but it was very unpopular with the neighbourhood when first built because of its bald modern design and materials. Modest, comfortable, liveable and architecturally transparent - it is a series of simple skillion boxes set on the slope and linked by a glazed entry hall that joins sleeping and living wings, with study perched above to form the only striking vertical element.

Later, when on my own, I begin the process of letting the house, its architecture and memories, unfold through my experience of being there and asking it to accommodate to my domestic routines. And through my photographing of it by roaming in a series of ever increasingly intimate cycles: house as container; house as lived space; house as my lived space?

Also I come to know it better through the reading of a small monograph written on the house that gives a rich biographical story that no experience of the place alone could reveal. In this book, Manning Clark's research assistant for the last 20 years of his life remembers the family in the house. She peoples the garden with stories of vegetables, pets, and cricket on the lawn. She directs the reader to go up to the small kitchen area, remembering: "Once the orders for the day had been completed, I was told to go downstairs and put the jug on for a cup of tea. This was shared with Dymphna if she was at home.” And in the evening late-staying guests such as Nolan, Boyd and Humphries assisted Dymphna with the mountains of washing up. Or go up the step-ladder to Clark's study for a memoire of struggles with health and personal demons, and sparring matches with Patrick White.

\section{EPISODE TWO: some haunting dreams}

This house is getting a bit overwhelming so I leave it and go out to a twilight viewing of the Ballet Russe exhibition of costumes at the National Gallery - including the famous ballet "Le Pavillon d'Armide". So the story goes, during a storm, a young Vicomte René de Beaugency seeks refuge in a castle owned by a magician. He spends the night in the room of a castle where a tapestry hangs on the wall. While asleep he dreams that the tapestry comes to life: the figures become animated around him in his room. The beautiful Sorceress Armide dances before him and gives him her scarf. When he awakes in the morning he finds he still holds the scarf, and Armide's likeness that is woven into the tapestry no longer wears the same scarf. René collapses with horror.

I am slightly dreading my first night of sleeping in this house, of dreaming of Manning Clark and in the morning finding his familiar hat has gone from its hook in the kitchen. I don't believe in ghosts but I lock the door to the bedroom just in case. In the morning I go to check the hat is still hanging in the kitchen. As the bedroom door shuts I realise I have locked my keys inside the bedroom and myself out. I fight my way through the overgrown bushes on the side of the house with a plastic chair and climb back through the bedroom window - always with the thought of being watched.

Breakfast: the kitchen drawers are deceptively shallow, and the contents of one spills on the kitchen floor. I hurry to carefully replace it - always with the thought of being watched.

Bedtime: the shower sets off the smoke alarm with the escaping steam. I de-alarm it by standing naked on a chair with the book step-ladder in hand - always with the thought of being watched. 
Peter Freeman writes:

I still expect to see them both when I come into the house. Manning sitting in that old brown chair with the reading light switched on, listening to the $\mathrm{ABC}$ news or to his music, or reading a book or a newspaper. Dymphna up in the kitchen area, either preparing food (always wearing an apron) or working at the typewriter. And I also expect to see Axel there too, making cups of strong coffee in the kitchen in the morning. Axel died in October 2001 of a brain tumour. (2002)

Uncanny houses?

Haunted houses?

What makes them so? The heritage home slips between genres, all the more so when spending time in the slightly illicit occupation of eaves-dropping on the intimate memories of the deceased that are powerfully bound up in a home. Familiarity and unfamiliarity make for the uncanny experience. Not easily translatable - not direct terror or mysticism. More a sense of what Vidler describes as lurking unease: "an uncomfortable sense of haunting rather than a present apparition”. The heritage house as an uncanny house? A dead home, a house as crypt for domestic routine?

By the third morning I have established a few of my own domestic routines in an attempt to create a small space of living in the present. But the only place that feels comfortable is perched at the table and chairs in the courtyard - half outside. After three days, though, I do start to think presumptuously of the house possibly becoming my own. I daydream of occupation by expunging away layers of previous inhabitation by cleaning and renovating away vestiges of the house's quirks and mannerisms.

Julie Myerson, writing on the historical biography of the many occupants of her own home, puts it better:

Most of us live in our homes knowing we're not the only ones to have done so. But we rarely confront those shadows in any significant way. Why should we? This is us and that was them. Their clutter, their smells, their noises, and their way of doing things is long gone. We've painted, plastered, demolished and constructed or converted ... Our moments have blotted out theirs. Maybe this is a necessary element of domestic living - maybe it's the only was we can co-exist comfortably with each other's past lives, each other's ghosts. (2005)

But here, in this preserved object, you must creep between those quirks and mannerisms. It reminds me of staying in my own former family home that carries an emotional burden around which the quirks and mannerisms must be endured because they are partly yours. All the while mindful of updating your own strategies for keeping memories contained and isolated from the everyday of here and now. All the while mindful of future strategies for managing this container of objects and memories. Does this act of staying in someone else's home illustrate the divide between memory and history? Do occupation and duration open receptivity to memory rather than history? 
Bachelard says that houses are experienced not from day to day, but through dreams. And only after we inhabit a new house do memories of other places we have lived in come back to us. We are never real historians, but through poems we touch the ultimate poetic depth of the space of the house. Well, here I think I am doing something else: capturing domestic functionality by use not by poetry: boiling the kettle, having tea and biscuits in the son's bed, climbing through windows and listening to the old stereo. The resurrection of mundane rituals seems to unlock my memories of other homes. In Bachelard's terms, staying in this house in contrast to touring this house unlocks a "topoanalysis"; a more systematic psychological study of sites and intimate lives.

\section{EPISODE THREE: climbing the stairs}

As Robin Boyd was leaving Canberra at the airport, Manning shouted to him across the tarmac: "Robin, is the house going to be single storey with my study in the basement?" After a moment's thought Boyd shouted back "Single storey with the study upstairs." And so it was prophesised that a lot of books would indeed be written in this room of great intellectual labour. History is the staging of events to a dramatic script.

It is a drizzly Sunday morning and by this third day I conquer the fear of the vertical extremities of the house and summon the courage to climb the steep stepladder designed to discourage "frivolous visitors" to the study - always with the feeling of being watched. Clark says: "The historian was like a person looking out of a window at the last. What he saw was human chaos. Like God he imposed order on the chaos." Looking out of this picture window, I see only the white cockatoos squawking in the trees.

Sitting at the desk, I fit my hand into the worn patch of grain on the desk and I set myself the task of transcribing some of Clark's words into my own hand-writing in the way that Le Corbusier used to incessantly trace over and re-trace, in his own sketchy hand, views taken from photographs and postcards as an act of immersion and appropriation. A good place to start seems like an abridged version of Manning Clark's History of Australia. For Clark, the exploration of other voices - at times deranged - was done as a covert operation. Clark believed that in order to tell a story well, the historian needed to create what he called indirect narrators. But he also admitted: "now I want to write history as a story - as an art".

I look around the study again. It holds to the illusion of having been barely disturbed since 1991. Yellowed and curling paintings and photos of Russian writers, Australian explorers and family members, all framed and pinned like specimens behind the door. Kept some 20 years after death like a furtive shrine or memorial to descendants and mentors and survivors. Clark admits to a series of "reading binges" here - Dostoevsky, Tolstoy, Shakespeare, Hardy and Dickens. By sitting here Clark takes ghostly shape as an active protagonist in the tragedies of his own writing. Paul Carter suggests that, "What Clark gives us, in fact, is a series of stage directions in which historical heroes are actors ... author included." Clark said: "The historian puts sinew and flesh on the dry bones of the dead. He performs the miracle of breathing life into dead bones." 
Is this house haunted?

Yes, in the last years of her life in the house Dymphna found it so: "it was as if something was springing from the shadows". Clark was everywhere in the house. Dymphna had changed it little since he had died, and facing her own death in the same house she felt Clark's presence more than at any point since his death. Myerson suggests that: "Past, present, and future collide in a single family house." This may be so in a "normal" house, but in museum-houses there is no hope of a future. In their uncanny state of suspended display, these houses attempt the impossible - to hold the dying breath of home for eternity and posterity.

In conclusion, I agree with David Malouf, who writes about attempts to open this door to collective memories and histories in any house as inevitably reaching limits - limits on how far we can or cannot physically penetrate as a witness. But we can open some door in ourselves. The taking up of slightly deranged, autobiographical writing in this piece is revelatory of an uncanny house experience, and an unexpected unlocking of a kind of topoanalysis. Whether this mode of documenting personal experience holds the key to the unlocking of other museum-houses remains to be tested more fully through more extended weekends!

\section{References}

Bachelard, G. (1997). Poetics of space. In N. Leach (Ed.). Re-thinking architecture. London: Routledge.

Carter, P. (1987). The road to Botany Bay. London: Faber and Faber.

Clark, M. (1992). A historian's apprenticeship. Melbourne: Melbourne University Press.

Creighton, T., Freeman, P., \& Russell, R. (2002). Reflections: Manning Clark's house. Canberra: Manning Clark Foundation.

Docker, J. (2000). Writing from fragments. In A. Curthroys \& A. McGrath (Eds.), Writing histories: Imagination and narration. Melbourne: Monash University Press.

Goffman, E. (1986). Frame analysis: An essay on the organization of experience. Boston, Mass.: Northeastern University Press.

Light, A. \& Smith, J. M. (2005). The aesthetics of everyday life. New York, NY: Columbia University Press.

Malouf, D. (1985). 12 Edmonston Street. London: Penguin Books

McKenna, M. (2011). An eye for eternity: The life of Manning Clark. Melbourne: Melbourne University Press.

Myerson, J. (2005). Home: The story of everyone who ever lived in our house. London: Harper Perennial.

Vidler, A. (1992). The architectural uncanny: Essay in the modern unhomely. Cambridge, Mass.: MIT Press. 